\title{
The Nonlinear Dynamic Relationship between Stock Prices and Exchange Rates in Asian Countries
}

\author{
Ryuta Sakemoto $^{1}$ \\ ${ }^{1}$ School of Social Sciences, Heriot-Watt University, Edinburgh, U.K. \\ Correspondence: Ryuta Sakemoto, School of Social Sciences, Heriot-Watt University, Edinburgh, U.K. EH14 4AS. \\ Tel: 44-131-451-3486. \\ Received: January 20, 2017 \\ Accepted: February 6, 2017 \\ Online Published: February 28, 2017 \\ doi:10.5430/ijfr.v8n2p40 \\ URL: http://dx.doi.org/10.5430/ijfr.v8n2p40
}

\begin{abstract}
This study explores dynamic relationships between stock prices and exchange rates in Asian countries. These relationships are complex and include both linear and nonlinear relationships. We employ a nonparametric causality test to explore them. The nonparametric causality test is more robust to a nonlinear relationship. The empirical results reveal that most countries have bi-directional causality relationships between stock prices and exchange rates. Some relationships are not captured by the linear model. These results support the theoretical model which shows dynamic interactions between stock and exchange rate markets. This study investigates the main driver to generate the nonlinear causality relatioships. The empirical results present that the main source for the nonlinearity is the volatility effects. In particular, they were substantial during the Asian and global financial crises. After controlling for the volatility effects, only one country shows the bi-directional causality relationship. In contrast to the previous studies, this study shows that the volatility effects are important between different asset markets. These findings suggest that controlling for exchange rate markets may be helpful to mitigate turmoil during a financial crisis.
\end{abstract}

Keywords: financial crisis, causality test, nonparametric method, nonlinearities, volatility effect

\section{Introduction}

The linkage between stock prices and exchange rates has been of interest to researchers for a long time. Two important theories that explain this relation are the flow-oriented model and the stock-oriented model. (Note 1) The flow-oriented model was first suggested by Dornbusch and Fischer (1980); since exchange rates alter a firm's international competitiveness, their model demonstrates that the movement of exchange rates impacts stock prices. In contrast, Branson (1983) and Frankel (1983) proposed the stock-oriented model. They describe the manner in which stock prices affect exchange rates in the following way: when the domestic country's stock prices increase, domestic consumption also increases, and this increases the domestic investors' demand for money. Therefore, the domestic interest rate becomes higher than the interest rates of other countries.

Empirical studies have found links between stock prices and exchange rates in developed countries. Ma and Kao (1990) use monthly data from six developed countries and found that the export-dominant countries had negative relations with currency appreciation. Ajayi and Mougoue (1996) report that an increase in domestic stock prices negatively impacted exchange rates in the short term and positively impacted exchange rates in the long term. Chow, Lee, \& Solt (1997) demonstrate that real exchange rates and stock returns were positively correlated in the long term in the U.S., while Nieh and Lee (2001) conclude that only short-run relationships exist between stock prices and exchange rates in the G7 countries. Recently, Phylaktis and Ravazzolo (2005) focus on Asian counties and show that there are long-run relationships among their stock prices, real exchange rate, and U.S. stock price. Causality tests are employed by Granger, Huang, \& Yang (2000) and Pan, Fok, \& Liu (2007) to examine the Asian financial crisis period.

In this study, we investigate the dynamic relationships between stock prices and exchange rates in Asian countries. Exploring Asian countries is important since they have had two crises in our sample period, which were the Asian financial crisis in 1997 and the global financial crisis in 2008. These crises, however, have several differences. For instance, Erb, Harvey, \& Viskanta (1998) and Ito (2007) point out that the Asian financial crisis was a currency crisis. Since this crisis, some Asian countries have accumulated international reserves to avoid a future currency crisis, as shown by Aizenman and Marion (2003) and Aizenman and Lee (2008). In contrast, the global financial crisis was led by complex financial instruments and financial markets were more integrated as pointed out by Claessens, Kose 
\& Terrones (2010). Lin (2012) addresses that after the global financial crisis, new money inflows to Asian countries occurred by quantitative easing policies conducted by the U.S., U.K., and Euro-zone.

Recent theoretical and simulation studies imply that the relationships between stock prices and exchange rates are complex. For instance, Dieci and Westerhoff (2010) propose a theoretical model which generates a dynamic relationship between stock markets and an exchange rate market. Their model has traders who trade based on fundamental information in the stock markets and heterogeneous traders in the exchange rate market, which contains both fundamental and technical traders. Corona, Ecca, Marchesi, \& Setzu (2008) examine the interactions between stock and exchange rate markets using an artificial market. They present that there are dynamic interactions even without any external news. Taken these theoretical and computer simulation models, the nonparametric approach which can capture both linear and nonlinear causality relationships is promising.

To this end, we use the nonparametric Granger causality test proposed by Diks and Panchenko (2006) (henceforth DP) is applied in this study. This method extends the studies of Baek and Brock (1992) and Hiemstra and Jones (1994) and is widely applied in several fields; exchange rate markets (Bekiros and Diks 2008a), energy markets (Bekiros and Diks 2008b), interest rates (Ajayi and Serletis 2009), and market sentiment (Dergiades 2012). This study differs from Yang, Tu, \& Zeng (2014), because our approach explores impacts of the volatility effects. The causality relationships might come from the conditional variance, as pointed out by Hiemstra and Jones (1994), and Bekiros and Diks (2008a). This study also takes into account a long-run relationship, since Bekiros and Diks (2008b) highlight that the co-integration relationship might affect the nonlinear causality result.

This study finds that the nonparametric method is successful in capturing the causal relationships which are not captured by the conventional method. We reveal that most Asian countries have bi-directional causality relationships between stock prices and exchange rates. More importantly, we present that the main driver for the nonlinear relationships is the volatility effects. All countries, except Singapore, lose the bi-directional causality relationships after controlling for the volatility effects.

This paper is organized as follows: Section 2 explains the methodologies; Section 3 describes the data; Section 4 reports the empirical results; Section 5 conducts further research; and Section 6 concludes the study.

\section{Methodologies}

\subsection{Testing Stationarity}

The DP nonparametric test requires stationary data series. For a stationary test, we employ the Modified Dickey and Fuller (DF-GLS) test proposed by Elliott, Rothenberg, \& Stock (1996). This test extends the Dickey and Fuller (1979) test and if the data series have a deterministic mean or trend, the asymptotic power of DF-GLS is greater than the conventional Augmented Dickey and Fuller (ADF) test. The test statistic $a_{0}$ is obtained as:

$$
y_{t}^{d}=a_{0} y_{t-1}^{d}+a_{1} \Delta y_{t-1}^{d}+\cdots+a_{p} \Delta y_{t-p}^{d}+\varepsilon_{t}
$$

where $y_{t}^{d}=y_{t}-\hat{\delta} z_{t} \cdot z_{t}$ contains a constant term and does not include a trend term in this study. The null hypothesis is $a_{0}=0$ and if there is no trend term, the Dickey-Fuller $t$ statistic is applied for a statistical inference as in Elliott et al. (1996). The number of lags in equation (1) is determined by the Bayesian information criterion (BIC).

\subsection{Cointegration Test}

We use the Johansen cointegration approach proposed by Johansen (1988) to investigate a long-run relationship between stock prices and exchange rates. We consider the following reduced form error correction model (ECM):

$$
\Delta z_{t}=\sum_{i=1}^{p-1} \Gamma_{i} \Delta z_{t-i}+\alpha \beta^{\prime}\left[\begin{array}{c}
Z_{t-1} \\
1
\end{array}\right]+\varepsilon_{t}
$$

where $z_{t}=\left[\begin{array}{lll}X_{1 t} & \cdots & X_{n t}\end{array}\right]^{\prime}, \alpha$ is a $n \times r$ matrix of short run adjustment parameters, $\beta$ is a $n \times r$ matrix of $r$ cointegration vectors, and $\varepsilon_{t}$ is the error term. The Johansen trace test statistic is employed in this study. The number of lags in equation (2) is determined by the BIC. The null hypothesis is that there are at most $r$ cointegration vectors $0 \leq r \leq n$ and the trace statistic is:

$$
\text { trace }=-T \sum_{i=r+1}^{n} \ln \left(1-\hat{\lambda}_{i}\right)
$$

where $\hat{\lambda}_{i}$ is the $n-r$ smallest squared canonical correlations of $\Delta z_{t}$ corrected for lagged differences and $T$ is the sample size. There are five specifications of equation (2) as in Johansen (1995). Although we use the Pantula 
principle to determine deterministic components of the model as in Nieh and Lee (2001), Hjelm and Johansson (2005) propose to exclude the no deterministic components model, since the model is too restrictive. The Pantula principle suggests the restricted constant model for all data.

\subsection{Nonparametric Granger Causality Test}

This subsection explains the DP nonparametric Granger causality test. First, it describes a conventional Granger causality test. The Granger (1969) causality test has been employed to show a dependence relation between time series data. Assuming that $\left\{X_{t}\right\}$ and $\left\{Y_{t}\right\}$ are scalar-valued, strictly stationary time series, $\left\{Y_{t}\right\}$ does not Granger cause $\left\{X_{t}\right\}$ if:

$$
H_{0}: Y_{t+1}\left|\left(\boldsymbol{X}_{\boldsymbol{t}}^{l_{X}} ; \boldsymbol{Y}_{\boldsymbol{t}}^{l_{Y}}\right) \sim Y_{t+1}\right| \boldsymbol{Y}_{\boldsymbol{t}}^{l_{Y}}
$$

where $\boldsymbol{X}_{\boldsymbol{t}}^{\boldsymbol{l}_{X}}=\left(X_{t-l_{X}+1}, \cdots, X_{t}\right), \boldsymbol{Y}_{\boldsymbol{t}}^{l_{Y}}=\left(Y_{t-l_{Y}+1}, \cdots, Y_{t}\right)$, and $l_{X}, l_{Y} \geq 0$. This relationship (4) is stated as the invariant distribution of the $\left(l_{X}+l_{Y}+1\right)$-dimensional vector $W_{t}=\left(\boldsymbol{X}_{t}^{l_{X}}, \boldsymbol{Y}_{t}^{l_{Y}}, Z_{t}\right)$, where $Z_{t}=Y_{t+1}$. Assuming that $l_{X}=l_{Y}=1$ and dropping the time index, the null hypothesis can be denoted in terms of the ratio of joint distributions. The joint probability density function $f_{X, Y, Z}(x, y, z)$ and its marginals satisfy the following relation under the null hypothesis:

$$
\frac{f_{X, Y, Z}(x, y, z)}{f_{Y}(y)}=\frac{f_{X, Y}(x, y)}{f_{Y}(y)} \frac{f_{Y, Z}(y, z)}{f_{Y}(y)} .
$$

DP propose the modified null hypothesis as:

$$
q=E\left[f_{X, Y, Z}(X, Y, Z) f_{Y}(Y)-f_{X, Y}(X, Y) f_{Y, Z}(Y, Z)\right]=0
$$

Finally, the test statistic $q$ is estimated as:

$$
T_{n}(\varepsilon)=\frac{(n-1)}{n(n-2)} \sum_{i}^{n}\left(\hat{f}_{X, Y, Z}\left(X_{i}, Y_{i}, Z_{i}\right) \hat{f}_{Y}\left(Y_{i}\right)-\hat{f}_{X, Y}\left(X_{i}, Y_{i}\right) \hat{f}_{Y, Z}\left(Y_{i}, Z_{i}\right)\right)
$$

where $\hat{f}_{w}$ is the local density estimator of a $d_{w}$-variate random vector $W$ at $W_{i}$, and $\hat{f}_{w}$ is denoted by an indicator function as follows:

$$
\hat{f}_{w}\left(W_{i}\right)=\frac{(2 \varepsilon)^{-d w}}{(n-1)} \sum_{j, j \neq i}^{n} I_{i j}^{W}
$$

where $I(\cdot)$ is the indicator function, when $I_{i j}^{W}=I\left(\left\|W_{i}-W_{j}\right\|<\varepsilon\right)$ equals 1 , and otherwise 0 . (Note 2) $\varepsilon$ is the bandwidth,

DP show that for $d_{X}=d_{Y}=d_{Z}=1$, if $\varepsilon=C n^{-\beta}$, where $C$ is any positive constant term and $\beta \in(1 / 4,1 / 3)$, then the estimated test statistic for (7) is asymptotically distributed as $N(0,1)$. Following DP, the bandwidth is set as: $\varepsilon=\min \left(C n^{-2 / 7}, 1.5\right)$.

This DP causality test is applied into residuals of a vector autoregression (VAR) model. Following to Pan et al. (2007) and Lin (2012), this study considers the following VAR model and controls for the interest spreads and stock returns in the Asian markets as follows:

$$
\begin{gathered}
\Delta S P_{t}=c_{0}+\sum_{k=1}^{p} c_{1 k} \Delta S P_{t-k}+\sum_{k=1}^{p} c_{2 k} \Delta E X_{t-k}+c_{3} S P R E A D_{t-1}+c_{4} A S I A_{t-1}+\varepsilon_{S P, t} \\
\Delta E X_{t}=\phi_{0}+\sum_{k=1}^{p} \phi_{1 k} \Delta S P_{t-k}+\sum_{k=1}^{p} \phi_{2 k} \Delta E X_{t-k}+\phi_{3} S P R E A D_{t-1}+\phi_{4} A S I A_{t-1}+\varepsilon_{E X, t}
\end{gathered}
$$

where $\triangle S P$ denotes the log difference of stock prices, $\triangle E X$ denotes the log difference of exchange rates, and $S P R E A D$ denotes the interest difference between the local interest rate and the U.S. interest rate. The local and U.S. interest rates are three-month deposit rates or three-month interbank rates. ASIA denotes the returns on an Asian stock index (MSCI All Country Asia excluding Japan), and is computed on the local currency. $\varepsilon_{S P, t}$ and $\varepsilon_{E X, t}$ are residuals of the VAR. The number of lags of the VAR model is determined by the BIC. 
When the stock price and the exchange rate are cointegrated, the error correction term is included in equations (9) and (10) as in Pan et al. (2007) and Bekiros and Diks (2008b). Since Granger (1988) and Bekiros and Diks (2008b) suggest that excluding the error correction term may cause a false causality result when there is a cointegration relationship.

\subsection{EGARCH Filter}

The nonparametric test can capture a nonlinear relationship and some portions of nonlinearity may be explained by the autoregressive conditional heteroscedasticity (ARCH) model as in Hsieh (1991). Nonparametric Granger causality tests are examined in terms of whether their results come from the volatility effects. Hiemstra and Jones (1994) and DP (2006) employ the Exponential -GARCH (EGARCH) model proposed by Nelson (1991) to capture the process of the conditional variance. This study also adopts the EGARCH model, since it can capture an asymmetric response of the variance as pointed out by Hsieh (1991). The conditional variance of $\sigma_{t}^{2}$ is modeled by $\operatorname{EGARCH}(1,1)$ as:

$$
\begin{gathered}
\varepsilon_{t} \sim N\left(0, \sigma_{t}^{2}\right) \\
\ln \left(\sigma_{t}^{2}\right)=\gamma_{0}+\gamma_{1} \ln \left(\sigma_{t-1}^{2}\right)+\gamma_{2}\left(\varepsilon_{t-1} / \sqrt{\sigma_{t-1}^{2}}\right)+\gamma_{3}\left(\left|\varepsilon_{t-1} / \sqrt{\sigma_{t-1}^{2}}\right|-\sqrt{2 / \pi}\right)
\end{gathered}
$$

where $\varepsilon_{t}$ is the residuals of the VAR model in (9) and (10), and $\gamma_{j}$ is the parameters of EGARCH. The asymmetric ARCH effect can be captured by $\gamma_{2}$ and $\gamma_{3}$. For the estimation, the EGARCH $(1,1)$ model is adopted, rather than using the BIC to determine the number of lags. Brooks (1996) proposes to use a compact representation model for the filtering. In addition, if higher lags are employed, most parameters become insignificant in this study.

\section{Data}

This section explains the data series. This study uses daily closing foreign exchange rates denoted relative to the U.S. dollar (USD) and daily closing stock price indices for eight Asian countries. All data are obtained from the Thomson Reuters Datastream. (Note 3)

Although data frequencies are important as in Huang and Jo (1995), and Narayan and Sharma (2015), this study focuses on daily frequency. The nonparametric test requires much more observations than a conventional method and monthly and weekly frequencies are difficult to collect enough observations. Moreover, Chamberlain, Howe, and Popper. (1997) show that low frequency data may not capture exchange rate exposure compare with daily frequency data. The sample period extends from November 2, 1995 to December 30, 2013.

Eight countries have been selected in this study: Indonesia, Korea, Japan, Hong Kong, Malaysia, the Philippines, Singapore and Thailand. Since these countries have been selected for study in most of the previous studies, it is possible to compare the results. The stock indices are Jakarta Stock Exchange Composite Index (Indonesia), Kospi200 (Korea), TOPIX (Japan), the Hang Seng Index (Hong Kong), FTSE Bursa Malaysia KLCI30 (Malaysia), Philippine SE Composite Index (Philippines), FTSE Straits Times Index (Singapore) and SET index (Thailand). These indices are based on local currencies and all data are transformed into logarithmic scale.

\section{Empirical Results}

\begin{tabular}{|c|c|c|c|c|c|c|c|}
\hline Country & & $t$-statistic & lags & & $t$-statistic & & lags \\
\hline \multirow[t]{2}{*}{ Indonesia } & SP & 0.82 & 1 & $\Delta \mathrm{SP}$ & -42.82 & ***** & 1 \\
\hline & EX & 0.27 & 21 & $\Delta \mathrm{EX}$ & 11.64 & $* * *$ & 20 \\
\hline \multirow[t]{2}{*}{ Korea } & SP & -0.80 & 1 & $\Delta \mathrm{SP}$ & 46.59 & $* * *$ & 1 \\
\hline & EX & -0.58 & 8 & $\Delta \mathrm{EX}$ & -3.51 & $* * *$ & 31 \\
\hline \multirow[t]{2}{*}{ Japan } & SP & -1.47 & 1 & $\Delta \mathrm{SP}$ & -1.43 & & 26 \\
\hline & EX & -1.54 & 1 & $\Delta \mathrm{EX}$ & -2.14 & $* *$ & 26 \\
\hline \multirow[t]{2}{*}{ Hong Kong } & SP & -0.46 & 1 & $\Delta \mathrm{SP}$ & -4.47 & $* * *$ & 19 \\
\hline & EX & -1.56 & 2 & $\Delta \mathrm{EX}$ & 51.87 & $* * *$ & 1 \\
\hline \multirow[t]{2}{*}{ Malaysia } & SP & -0.73 & 5 & $\Delta \mathrm{SP}$ & -1.74 & $*$ & 24 \\
\hline & EX & -0.31 & 30 & $\Delta \mathrm{EX}$ & -8.39 & $* * *$ & 30 \\
\hline \multirow[t]{2}{*}{ Philippines } & SP & -0.54 & 1 & $\Delta \mathrm{SP}$ & -4.42 & $* * *$ & 17 \\
\hline & EX & 0.26 & 12 & $\Delta \mathrm{EX}$ & -7.37 & $* * *$ & 16 \\
\hline \multirow[t]{2}{*}{ Singapore } & SP & $-1.64 *$ & 1 & $\Delta \mathrm{SP}$ & -45.05 & $* * *$ & 1 \\
\hline & EX & -0.65 & 1 & $\Delta \mathrm{EX}$ & -10.58 & $* * *$ & 16 \\
\hline \multirow[t]{2}{*}{ Thailand } & SP & -0.89 & 1 & $\Delta \mathrm{SP}$ & -9.47 & $* * *$ & 12 \\
\hline & EX & -0.40 & 1 & $\Delta \mathrm{EX}$ & -8.81 & $* * * *$ & 18 \\
\hline
\end{tabular}

Table 1. Results of DF-GLS test 
Descriprion: The table shows the result of the DF-GLS test as in Elliott et al. (1996) and the estimation model is equation (1). The number of lags is determined by the BIC. SP denotes the level and $\Delta$ SP denotes the log difference of stock prices and EX denotes the level and $\triangle \mathrm{EX}$ denotes the log difference of exchange rates. $* * *$, and $* * *$ indicates that the null hypothesis is rejected at the $10 \%, 5 \%$, and $1 \%$ level, respectively.

We begin with the unit root test results. Table 1 presents the results of the DF-GLS test. All logarithm level data appear to be nonstationary. In contrast, most first difference data (return data) seems to be stationary, except the stock return in Japan. In addition, the stock return in Malaysia can reject the null hypothesis only at the $10 \%$ level. These two results are not consistent with the previous studies such as Nieh and Lee (2001) and Pan et al. (2007), which apply other unit root tests. The first difference data are widely used in this field, and we avoid doing further transformation. In fact, we employ other unit root tests which include the ADF, Phillipps and Perron (PP 1988), and Kwiatkowski, Phillips, Schmidt, and Shin (KPSS 1992). These tests indicate that the stock returns in Japan and Malaysia are stationary and hence we regard all first difference data as stationary. (Note 4)

Table 2 shows the results of the Johansen cointegration test, as all level data suggest the I(1) process in Table 1. When we use level data, we cannot reject the null hypothesis that there are zero cointegration vectors at the $5 \%$ level, except Hong Kong. There are no long-run relationships between stock and exchange rate returns consistent with the findings of Nieh and Lee (2001) and Pan et al. (2007), while the result of Hong Kong indicates that there is one cointegration vector.

Table 2. Results of cointegration test

\begin{tabular}{|c|c|c|c|c|}
\hline Country & & Trace & $95 \% \mathrm{CV}$ & lags \\
\hline \multirow[t]{2}{*}{ Indonesia } & $\mathrm{r}=0$ & 15.93 & 19.96 & 2 \\
\hline & $r \leq 1$ & 5.16 & 9.42 & \\
\hline \multirow[t]{2}{*}{ Japan } & $r=0$ & 9.15 & 19.96 & 2 \\
\hline & $r \leq 1$ & 2.47 & 9.42 & \\
\hline \multirow{2}{*}{ Korea } & $\mathrm{r}=0$ & 15.96 & 19.96 & 3 \\
\hline & $r \leq 1$ & 3.82 & 9.42 & \\
\hline \multirow[t]{2}{*}{ Hong Kong } & $r=0$ & $22.05 * *$ & 19.96 & 2 \\
\hline & $r \leq 1$ & 4.29 & 9.42 & \\
\hline \multirow[t]{2}{*}{ Malaysia } & $\mathrm{r}=0$ & 14.18 & 19.96 & 5 \\
\hline & $r \leq 1$ & 1.82 & 9.42 & \\
\hline \multirow[t]{2}{*}{ Philippines } & $r=0$ & 16.93 & 19.96 & 3 \\
\hline & $r \leq 1$ & 2.66 & 9.42 & \\
\hline \multirow[t]{2}{*}{ Singapore } & $\mathrm{r}=0$ & 8.66 & 19.96 & 2 \\
\hline & $r \leq 1$ & 0.55 & 9.42 & \\
\hline \multirow[t]{2}{*}{ Thailand } & $r=0$ & 17.57 & 19.96 & 2 \\
\hline & $r \leq 1$ & 1.30 & 9.42 & \\
\hline
\end{tabular}

Descriprion: This table shows the results of the Johansen cointegration test. Trace is the trace test statistic and the null hypothesis is that there are at most $r$ cointegration vectors. $95 \% \mathrm{CV}$ is the $95 \%$ of the critical values from Osterwald-Lenum (1992). The number of lags is determined by the BIC. ***, and *** indicates that the null hypothesis is rejected at the $10 \%, 5 \%$, and $1 \%$ level, respectively.

We move onto the main results in Table 3 providing the Granger causality results. First we focus on the linear causality test in column (1). The stock returns Granger cause the exchange rate returns in Indonesia at the $1 \%$ level and in Singapore at the 5\% level. Thailand has the opposite relation and Japan, Korea, and the Philippines have bi-directional relationships. Malaysia does not have any relationships. This country has had a fixed exchange rate regime for several years, which may cause the weak relationship.

Given the linear results, we examine the nonparametric results in column (2) of Table 3. The nonparametric test can capture both linear and nonlinear relationships. All linear causality relationships remain statistically significant at least at the 5\% level in column (2). Interestingly, the nonparametric test is successful in capturing additional relationships in Indonesia, Singapore, and Thailand. These indicate the advantage of applying the nonparametric 
method. The nonparametric results suggest that all countries except Malaysia have bi-directional relationships. These imply that the relationships between stock prices and exchange rates are dynamic and are supportive of the theoretical model of Dieci and Westerhoff (2010). It is difficult to conclude whether the stock-oriented or flow-oriented models determine the relationships.

Table 3. Results of Granger causality test

\begin{tabular}{|c|c|c|c|c|}
\hline & & \multicolumn{3}{|c|}{ Panel A: VAR } \\
\hline & & \multirow{2}{*}{$\begin{array}{l}\text { Linear } \\
\text { (1) }\end{array}$} & \multicolumn{2}{|c|}{ Nonparametric } \\
\hline & & & $\begin{array}{l}\text { Residual } \\
\text { (2) }\end{array}$ & $\begin{array}{l}\text { EGARCH } \\
\text { (3) }\end{array}$ \\
\hline \multirow[t]{2}{*}{ Indonesia } & $\Delta \mathrm{EX} \neq \geq \Delta \mathrm{SP}$ & & $* * *$ & $* * *$ \\
\hline & $\Delta \mathrm{SP} \neq \geq \Delta \mathrm{EX}$ & $* * *$ & $* * *$ & \\
\hline \multirow[t]{2}{*}{ Japan } & $\Delta \mathrm{EX} \neq \geq \Delta \mathrm{SP}$ & $* * *$ & $* * *$ & $* *$ \\
\hline & $\Delta \mathrm{SP} \neq \geq \Delta \mathrm{EX}$ & $* *$ & $* * *$ & \\
\hline \multirow[t]{2}{*}{ Korea } & $\Delta \mathrm{EX} \neq \geq \Delta \mathrm{SP}$ & $* * *$ & $* * *$ & \\
\hline & $\Delta \mathrm{SP} \neq \geq \Delta \mathrm{EX}$ & $* * *$ & $* *$ & \\
\hline \multirow[t]{2}{*}{ Malaysia } & $\Delta \mathrm{EX} \neq \geq \Delta \mathrm{SP}$ & & & \\
\hline & $\Delta \mathrm{SP} \neq \geq \Delta \mathrm{EX}$ & & & \\
\hline \multirow[t]{2}{*}{ Philippines } & $\Delta \mathrm{EX} \not \geq \Delta \mathrm{SP}$ & $* * *$ & $* * *$ & \\
\hline & $\Delta \mathrm{SP} \neq \geq \Delta \mathrm{EX}$ & $* * *$ & $* * *$ & $* *$ \\
\hline \multirow[t]{2}{*}{ Singapore } & $\Delta \mathrm{EX} \neq \geq \Delta \mathrm{SP}$ & & $* * *$ & $* *$ \\
\hline & $\Delta \mathrm{SP} \neq \geq \Delta \mathrm{EX}$ & $* *$ & $* * *$ & $* *$ \\
\hline \multirow[t]{5}{*}{ Thailand } & $\Delta \mathrm{EX} \neq \geq \Delta \mathrm{SP}$ & $* * *$ & $* * *$ & \\
\hline & $\Delta \mathrm{SP} \neq \geq \Delta \mathrm{EX}$ & & $* * *$ & \\
\hline & & \multicolumn{3}{|c|}{ Panel B: VEC } \\
\hline & & Linear & Nonpar & ametric \\
\hline & & (4) & $\begin{array}{l}\text { Residual } \\
\text { (5) }\end{array}$ & \\
\hline \multirow[t]{2}{*}{ Hong Kong } & $\Delta \mathrm{EX} \neq \geq \Delta \mathrm{SP}$ & & $* * *$ & \\
\hline & $\Delta \mathrm{SP} \neq \geq \Delta \mathrm{EX}$ & & $* * *$ & \\
\hline
\end{tabular}

Descriprion: This table shows the results of linear and nonparametric Granger causality tests. The symbol " $\neq \gg$ " implies does not Granger-cause. $\triangle \mathrm{SP}$ is log difference of stock prices and $\triangle \mathrm{EX}$ is the log difference of exchange rates. Panel A uses the linear VAR estimated by equations (9) and (10). The nonparametric result is estimated by the nonparametric Granger causality test using the residuals of the VAR. EGARCH indicates the residuals of the VAR are filtered by the EGACRH model as in equations (11) and (12). Panel B uses the VEC model which adds the error correction term into the VAR. **, and *** indicate that the null hypothesis is rejected at the $5 \%$ and $1 \%$ level, respectively.

The next test assesses whether the volatility effects impact the nonparametric causality test. Hsieg (1991) highlights that the volatility effects cause nonlinearities in stock returns and Brook (1996) finds the same results in exchange rate markets. We conduct the nonparametric causality test after filtering the residuals of equations (9) and (10) using the EGACRCH model. Column (3) in Table 3 provides evidence that more than half of the causality relationships become insignificant after the EGARCH filtering. All countries, except Singapore, do not have the bi-directional relationships.

Theses imply that conditional volatility is a main determinant of the nonlinear causality relationships. In contrast to the previsus studies, we find that the volatility effects are important between the different asset markets.

Finally, we focus on columns (4) and (5) which are estimated using the residuals of the vector error correction (VEC) model, since Table 2 suggests that there is a long-run relationship in Hong Kong. We can see the nonparametric test in column (5) captures the feedback relationships not revealed by the conventional model in column (4). In summary, all countries except Malaysia have bi-directional causality relationships for the entire sample period. 


\section{Further Investigation}

This section conducts a sub-sample analysis. This study focuses on two financial crises. The two financial crises have different characteristics and previous empirical studies also show different causality relationships. Lin (2012) finds that the causality relationships are stronger in the global financial crisis than those in the Asian financial crisis using

Table 4. Results of cointegration test during crises

\begin{tabular}{|c|c|c|c|c|c|}
\hline \multirow[b]{2}{*}{ Country } & \multicolumn{3}{|c|}{ Asian crisis } & \multicolumn{2}{|c|}{ Global crisis } \\
\hline & & Trace & lags & Trace & lags \\
\hline \multirow[t]{2}{*}{ Indonesia } & $\mathrm{r}=0$ & 11.61 & 2 & 18.90 & 2 \\
\hline & $r \leq 1$ & 4.57 & & 1.73 & \\
\hline \multirow[t]{2}{*}{ Japan } & $\mathrm{r}=0$ & 11.37 & 1 & 8.27 & 3 \\
\hline & $r \leq 1$ & 5.01 & & 2.62 & \\
\hline \multirow[t]{2}{*}{ Korea } & $\mathrm{r}=0$ & 8.11 & 3 & 12.52 & 1 \\
\hline & $r \leq 1$ & 1.38 & & 1.53 & \\
\hline \multirow[t]{2}{*}{ Hong Kong } & $\mathrm{r}=0$ & 11.98 & 2 & 13.91 & 1 \\
\hline & $r \leq 1$ & 3.06 & & 3.37 & \\
\hline \multirow[t]{2}{*}{ Malaysia } & $\mathrm{r}=0$ & 13.16 & 1 & 7.42 & 2 \\
\hline & $r \leq 1$ & 2.20 & & 0.51 & \\
\hline \multirow[t]{2}{*}{ Philippines } & $\mathrm{r}=0$ & 15.16 & 2 & 11.74 & 2 \\
\hline & $r \leq 1$ & 2.93 & & 0.82 & \\
\hline \multirow[t]{2}{*}{ Singapore } & $\mathrm{r}=0$ & 10.83 & 2 & 11.05 & 1 \\
\hline & $r \leq 1$ & 0.93 & & 0.52 & \\
\hline \multirow[t]{2}{*}{ Thailand } & $\mathrm{r}=0$ & 19.72 & 1 & 7.52 & 1 \\
\hline & $r \leq 1$ & 1.59 & & 0.29 & \\
\hline
\end{tabular}

Descriprion: This table shows the results of Johansen cointegration test. Trace is the trace test statistic and the null hypothesis is that there are at most $r$ cointegration vectors. Asian crisis is from July 1, 1997 to July 30, 1999 and Global crisis is from March 3, 2008 to December 30, 2010. The number of lags is determined by the BIC. *,**, and *** indicates that the null hypothesis is rejected at the $10 \%, 5 \%$, and $1 \%$ level, respectively.

the linear causality test and monthly data. Here the crisis periods are defined according to Lin (2012). The Asian financial crisis is from July 1, 1997 to July 30, 1999 and the global financial crisis is from March 3, 2008 to December 30, 2010.

Table 4 demonstrates the results of the Johansen cointegration test during the crises. All countries suggest that there is no cointegration. Phylaktis and Ravazzolo (2005) present that the cointegration relationships become weaker during the Asian crisis period; our results are supportive of their findings. Moreover, our results confirm there is a similar pattern during the global financial crisis. 
Table 5. Results of Granger causality test during crises

\begin{tabular}{|c|c|c|c|c|c|c|c|}
\hline & & \multicolumn{3}{|c|}{ Asian crisis } & \multicolumn{3}{|c|}{ Global crisis } \\
\hline & & \multirow{2}{*}{$\begin{array}{l}\text { Linear } \\
(1)\end{array}$} & \multicolumn{2}{|c|}{ Nonparametric } & \multirow{2}{*}{$\begin{array}{l}\text { Linear } \\
\text { (4) }\end{array}$} & \multicolumn{2}{|c|}{ Nonparametric } \\
\hline & & & $\begin{array}{l}\text { Residual } \\
\text { (2) }\end{array}$ & $\begin{array}{l}\text { EGARCH } \\
\text { (3) }\end{array}$ & & $\begin{array}{l}\text { Residual } \\
(5)\end{array}$ & $\begin{array}{l}\text { EGARCH } \\
(6)\end{array}$ \\
\hline \multirow[t]{2}{*}{ Indonesia } & $\Delta \mathrm{EX} \neq \geq \Delta \mathrm{SP}$ & & $* * *$ & $* * *$ & $* * *$ & $* * *$ & $* * *$ \\
\hline & $\Delta \mathrm{SP} \neq \geq \Delta \mathrm{EX}$ & $* * *$ & $* *$ & & $* * *$ & $* * *$ & \\
\hline \multirow[t]{2}{*}{ Japan } & $\Delta \mathrm{EX} \neq \geq \Delta \mathrm{SP}$ & & $* *$ & & $* *$ & $* * *$ & \\
\hline & $\Delta \mathrm{SP} \neq \geq \Delta \mathrm{EX}$ & & & & & $* * *$ & \\
\hline \multirow[t]{2}{*}{ Korea } & $\Delta \mathrm{EX} \not \geq \Delta \mathrm{SP}$ & $* * *$ & $* * *$ & & $* * *$ & $* * *$ & $* * *$ \\
\hline & $\Delta \mathrm{SP} \neq \geq \Delta \mathrm{EX}$ & & $* * *$ & & $* * *$ & $* * *$ & \\
\hline \multirow[t]{2}{*}{ Hong Kong } & $\Delta \mathrm{EX} \neq \geq \Delta \mathrm{SP}$ & & & & & & \\
\hline & $\Delta \mathrm{SP} \neq \geq \Delta \mathrm{EX}$ & & & & & & \\
\hline \multirow[t]{2}{*}{ Malaysia } & $\Delta \mathrm{EX} \not \geq \Delta \mathrm{SP}$ & $* * *$ & $* *$ & & & & \\
\hline & $\Delta \mathrm{SP} \neq \geq \Delta \mathrm{EX}$ & & $* *$ & & & $* *$ & \\
\hline \multirow[t]{2}{*}{ Philippines } & $\Delta \mathrm{EX} \neq \geq \Delta \mathrm{SP}$ & $* *$ & $* *$ & & & & \\
\hline & $\Delta \mathrm{SP} \neq \geq \Delta \mathrm{EX}$ & $* * *$ & $* * *$ & $* *$ & & & \\
\hline \multirow[t]{2}{*}{ Singapore } & $\Delta \mathrm{EX} \neq \geq \Delta \mathrm{SP}$ & & $* *$ & & & & \\
\hline & $\Delta \mathrm{SP} \neq \geq \Delta \mathrm{EX}$ & $* *$ & & & & $* *$ & \\
\hline \multirow[t]{2}{*}{ Thailand } & $\Delta \mathrm{EX} \neq \geq \Delta \mathrm{SP}$ & & $* *$ & & $* *$ & $* *$ & $* *$ \\
\hline & $\Delta \mathrm{SP} \neq \geq \Delta \mathrm{EX}$ & $* * *$ & & & & & \\
\hline
\end{tabular}

Descriprion: This table shows the results of linear and nonparametric Granger causality tests. The symbol " $\neq \gg$ ” implies does not Granger-cause. $\Delta \mathrm{SP}$ is log difference of stock prices and $\triangle \mathrm{EX}$ is the log difference of exchange rates. The linear VAR is estimated by equations (9) and (10). The nonparametric result is estimated by the nonparametric Granger causality test using the residuals of the VAR. EGARCH indicates the residuals of the VAR are filtered by the EGACRH model as in equations (11) and (12). Asian crisis is from July 1, 1997 to July 30, 1999 and Global crisis is from March 3, 2008 to December 30, 2010.**, and *** indicate that the null hypothesis is rejected at the $5 \%$ and $1 \%$ level, respectively.

Given the cointegration test results, we move onto the causality test. We employ the log first difference data and do not include the error correction term. Table 5 shows the results of the causality test. Columns (1) and (2) show that the nonparametric test captures the relationships which are not captured by the linear causality test. Indonesia, Korea, Malaysia, and the Philippines have bi-directional relationships during the Asian crisis and the exchange rate returns Granger cause the stock price returns in Japan, Singapore, and Thailand. These results imply that the Asian crisis affects the exchange rate markets and consistent with the view of Erb et al. (1998) and Ito (2007). Surprisingly, after the EGARCH filter, only two relationships remain statistically significant in column (3). The volatility effects have greater impacts on the causality relationships during the Asian crisis.

Indonesia, Japan and Korea have feedback relationships between exchange rate returns and stock returns during the global crisis in column (5). In contrast, the stock returns Granger cause exchange rate returns in Malaysia and Singapore, and the opposite relation holds in Thailand. Most relationships become insignificant after the EGRACH filter and these are similar to the results during the Asian crisis. We can find that the volatility effects are substantial for the nonlinear causality relationships during both crises.

\section{Conclusion}

This study has explored the causal relationship between exchange rates and stock prices. The relationship has dynamic interaction. For instance, Dieci and Westerhoff (2010) and Corona et al. (2008) propose theoretical or simulation models to capture the dynamics. This dynamic relationship causes difficulty to explore a causal relationship using a conventional Granger causality method. To capture the dynamic relationship, we employ the nonparametric Granger causality test proposed by Diks and Panchenko (2006). This approach is more robust to nonlinear relationships. 
We focus on eight Asian countries which have experienced two financial crises, which are the Asian financial crisis in 1997 and the global financial crisis in 2008. These two crises have different characteristics. For example, the Asian financial crisis is triggered by the currency markets in the emerging countries, while the global financial crisis is driven by the complex financial products in the developed markets.

The empirical results reveal that the nonparametric method is successful in capturing the causality relationships which are not captured by the linear causality test. Most countries have feedback relationships between stock and exchange rates. The volatility effects are strongly linked to the nonlinear causality relationships. In particular, the volatility effects play substantial roles during the financial crises. These findings suggest that economic policy to reduce volatility in the exchange rate such as a pegged exchange rate system may be helpful to mitigate the dynamic relationships during a crisis.

\section{References}

Aizenman, J., \& Lee, J. (2008). Financial versus monetary mercantilism: long-run view of large international reserves hoarding. World Economy, 31, 593-611. http://dx.doi.org/10.1111/j.1467-9701.2008.01095.x

Aizenman, J., \& Marion, N.P. (2003). The high demand for international reserves in the Far East: what is going on?. Japanese and International Economies , 17, 370-400. http://dx.doi.org/10.1016/S0889-1583(03)00008-X

Ajayi, R., \& Mougoue, M. (1996). On the dynamic relation between stock prices and exchange rates. Journal of Financial Research, 19(2), 193-207. http://dx.doi.org/10.1111/j.1475-6803.1996.tb00593.x

Ajayi, R., \& Serletis, A. (2009). Testing for causality in the transmission of Eurodollar and US interest rates. Applied Financial Economics, 19(6), 439-443. http://dx.doi.org/10.1080/09603100801964420

Baek, E.G., \& Brock, W.A. (1992). A general test for non-linear Granger causality: bivariate model. Iowa State University and University of Wisconsin, Madison: Working paper.

Bekiros, S.D., \& Diks, C.G. (2008a). The nonlinear dynamic relationship of exchange rates: parametric and nonparametric causality testing. Journal of Macroeconomics, 30(4), 1641-1650. http://dx.doi.org/10.1016/j.jmacro.2008.04.001

Bekiros, S.D., \& Diks, C.G. (2008b). The relationship between crude oil spot and futures prices: cointegration, linear and nonlinear causality. Energy Economics, 30, 2673-2685. http://dx.doi.org/10.1016/j.eneco.2008.03.006

Branson, W.H. (1983). Macroeconomic determinants of real exchange rate risk. In R. J. Herring (Eds), Managing Foreign Exchange Risk. Cambridge, MA: Cambridge University Press.

Brooks, C. (1996). Testing for non-linearity in daily sterling exchange rate. Applied Financial Economics, 6, 307-317. http://dx.doi.org/10.1080/096031096334105

Chamberlain, S., Howe, J.S., \& Popper, H. (1997). The exchange rate exposure of U.S. and Japanese banking institutions. Journal of Banking and Finance, 21, 871-892. http://dx.doi.org/10.1016/S0378-4266(97)00002-2

Chow, E.H., Lee, W.Y., \& Solt, M.E. (1997). The exchange-rate risk exposure of asset returns. Journal of Business, 70(1), 105-123. http://dx.doi.org/10.1086/209710

Claessens, S., Kose, M.A., \& Terrones, M.E. (2010). The global financial crisis:how similar? How different? How costly? Journal of Asian Economics, 21(3), 247-264.

Corona, E., Ecca, S., Marchesi, M., \& Setzu, A. (2008). The interplay between two stock markets and a related foreign exchange market: a simulation approach. Computational Economics, 32, 99-119. http://dx.doi.org/10.1007/s10614-008-9135-5

Dergiades, T. (2012). Do investors' sentiment dynamics affect stock returns? Evidence from the US economy. Economics Letters, 116(3), 404-407. http://dx.doi.org/10.1016/j.econlet.2012.04.018

Dickey, D., \& Fuller, W. (1979). Distribution of the estimators for autoregressive time series with a unit root. Journal of American Statistical Association, 74, 427-431. http://dx.doi.org/10.1080/01621459.1979.10482531

Dieci, R., \& Westerhoff, F. (2010). Heterogeneous speculators, endogenous fluctuations and interacting markets: A model of stock prices and exchange rates. Journal of Economic Dynamics and Control, 34, 743-764. http://dx.doi.org/10.1016/j.jedc.2009.11.002

Diks, C., \& Panchenko, V. (2006). A new statistic and practical guidelines for nonparametric Granger causality testing. Journal of Economic Dynamics and Control, 30(9-10), 1647-1669. http://dx.doi.org/10.1016/j.jedc.2005.08.008 
Dornbusch, R., \& Fischer, S. (1980). Exchange rates and the current account. American Economic Review, 70(5), 960-971.

Elliott, G., Rothenberg, T., \& Stock, J. (1996). Efficient tests for an autoregressive unit root. Econometrica, 64, 813-836. http://dx.doi.org/10.2307/2171846

Erb, C.B., Harvey, C.R., \& Viskanta, T. (1998). Contagion and risk. Emerging Markets Quarterly, 2, 46-64.

Frankel, J. (1983). Monetary and portfolio-balance models of exchange rate determination. In J. S. Bhandari, \& B. H. Putnam (Eds.), Economic Interdependence and Flexible Exchange Rates (pp. 84-115). Cambridge, MA: MIT Press.

Granger, C.W. (1969). Investigating causal relations by econometric models and cross-spectral methods. Econometrica, 37(3), 424-438. http://dx.doi.org/10.2307/1912791

Granger, C.W. (1988). Some recent development in a concept of causality. Journal of Econometrics, 39, 199-211. http://dx.doi.org/10.1016/0304-4076(88)90045-0

Granger, C.W., Huang, B.N., \& Yang, C.W. (2000). A bivariate causality between stock prices and exchange rates: evidence from recent Asianflu. The Quarterly Review of Economics and Finance, 40(3), 337-354. http://dx.doi.org/10.1016/S1062-9769(00)00042-9

Hiemstra, C., \& Jones, J.D. (1994). Testing for linear and nonlinear Granger causality in the stock price-volume relation. Journal of Finance, 49(5), 1639-64. http://dx.doi.org/10.1111/j.1540-6261.1994.tb04776.x

Hjelm, G., \& Johansson, M.W. (2005). A monte carlo study on the pitfalls in determining deterministic components in cointegrating models. Journal of Macroeconomics, 27, 691-703. http://dx.doi.org/10.1016/j.jmacro.2004.03.005

Hsieh, D. (1991). Chaos and nonlinear dynamics: application to financial markets. Journal of Finance, 46, 1839-1877. http://dx.doi.org/10.1111/j.1540-6261.1991.tb04646.x

Huang, R.D., \& Jo, H. (1995). Data frequency and the number of factors in stock returns. Journal of Banking and Finance, 19, 987-1003. http://dx.doi.org/10.1016/0378-4266(94)00066-C

Ito, T. (2007). Asian currency crisis and the International Monetary Fund, 10 years later: overview. Asian Economic Policy Review, 2, 16-49. http://dx.doi.org/10.1111/j.1748-3131.2007.00046.x

Johansen, S. (1988). Statistical analysis of cointegration vectors. Journal of Economic Dynamics and Control, 12, 231-254. http://dx.doi.org/10.1016/0165-1889(88)90041-3

Johansen, S. (1995). Likelihood-Based Inference in Cointegrated Vector Autoregressive Models. Oxford: Oxford University. http://dx.doi.org/10.1093/0198774508.001.0001

Kwiatkowski, D., Phillips, P.C., Schmidt, P., \& Shin, Y. (1992). Testing the null hypothesis of stationarity against the alternative of a unit root: How sure are we that economic time series have a unit root? Journal of Econometrics, 54, 159-178. http://dx.doi.org/10.1016/0304-4076(92)90104-Y

Lin, C.H. (2012). The comovement between exchange rates and stock prices in the Asian emerging markets. International Review of Economics and Finance, 22(1), 161-172. http://dx.doi.org/10.1016/j.iref.2011.09.006

Ma, C.K., \& Kao, W.G. (1990). Exchange rate changes and stock price reaction. Journal of Business Finance \& Accounting, 17, 441-449. http://dx.doi.org/10.1111/j.1468-5957.1990.tb01196.x

Narayan, P., \& Sharma, S.S. (2015). Does data frequency matter for the impact of forward premium on spot exchange rate? International Review of Financial Analysis, 39, 45-53. http://dx.doi.org/10.1016/j.irfa.2015.01.011

Nelson, D.B. (1991). Conditional heteroskedasticity in asset returns: a new approach. Econometrica, 59(2), 347-70. http://dx.doi.org/10.2307/2938260

Nieh, C.C., \& Lee, C.F. (2001). Dynamic relationship between stock prices and exchange rates for G-7 countries. The Quarterly Review of Economics and Finance, 41, 477-490. http://dx.doi.org/10.1016/S1062-9769(01)00085-0

Osterwald-Lenum, M. (1992). A note with quantiles of the asymptotic distribution of the maximum likelihood cointegration rank test statistics. Oxford Bulletin of Economics and Statistics, 54, 461-472. http://dx.doi.org/10.1111/j.1468-0084.1992.tb00013.x 
Pan, M.S., Fok, R.C.W., \& Liu, Y.A. (2007). Dynamic linkages between exchange rates and stock prices: evidence from east Asian markets. International Review of Economics and Finance, 16(4), 503-520. http://dx.doi.org/10.1016/j.iref.2005.09.003

Phillips, P.C., \& Perron, P. (1988). Testing for a unit root in time series regression. Biometrika, 75, 335-346. http://dx.doi.org/10.1093/biomet/75.2.335

Phylaktis, K., \& Ravazzolo, F. (2005). Stock prices and exchange rate dynamics. Journal of International Money and Finance, 24, 1031-1053. http://dx.doi.org/10.1016/j.jimonfin.2005.08.001

Yang, Z., Tu, A. H., \& Zeng, Y. (2014). Dynamic linkages between Asian stock prices and exchange rates: new evidence from causality in quantiles. Applied Economics, 46(11), 1184-1201. http://dx.doi.org/10.1080/00036846.2013.868590

\section{Notes}

Note 1. The flow-oriented model is known as the balance of trade model or the goods market model. The stock-oriented model is called the portfolio balance model or the asset market model.

Note 2. $\|x\|$ indicates the supremum norm.

Note 3. The interest rates and the MSCI All country Asia index are obtained from Datastream.

Note 4. These results are available from the authors upon request. 